\title{
DINAMIKA KELOMPOK TANI MAESAAN WAYA DI DESA MANEMBO, KECAMATAN LANGOWAN SELATAN
}

\author{
Juwendi Poluan \\ Ventje V. Rantung \\ Charles R. Ngangi
}

\begin{abstract}
ABSRACT
This research aims to identify the dynamics of Maesaan Waya Agriculture group which was studied by group dynamics elements namely the purpose of the group, the structure of the group, the building and the developing of the group, the unity of the group and the effectivity of the group. This research was conducted from October 2016 to April 2017 on Maesaan Waya Agriculture group in Manembo Village, South Langowan Subdistrict. The collecting of the data included primary and secondary data. Primary data was collected by direct interview using questionnaire with agriculture group members who were become respondents. The total number of respondents in this research is 20 respondents. The secondary data were collected from research-related literatures. Descriptive analysing was the method in data analyzing. The result of this research shows that the dynamics of Maesaan Waya agriculture group is categorized as dynamic with $80 \%$ valuation percentage. This is because the elements of group dynamics in Maesaan Waya agriculture group run well. Even though the elements of group dynamics run well, there was $20 \%$ dynamics elements categorized as less-dynamic.
\end{abstract}

Keywords: dynamics, farmers group, Maesaan Waya, Manembo Village, South Langowan Sub-district, Minahasa District

\begin{abstract}
ABSTRAK
Penelitian ini bertujuan untuk mengetahui dinamika kelompok tani Maesaan Waya yang dikaji dari unsur-unsur dinamika kelompok yaitu, tujuan kelompok, struktur kelompok, pengembangan dan pembinaan kelompok, kekompakan kelompok, dan efektivitas kelompok. Penelitian ini telah dilaksanakan sejak bulan Oktober 2016 sampai bulan April 2017 pada Kelompok Tani Maesaan Waya di Desa Manembo, Kecamatan Langowan Selatan. Pengumpulan data meliputi data primer dan data sekunder. Data primer diperoleh dari wawancara langsung dari anggota kelompok tani yang menjadi responden dengan menggunakan kuisioner. Jumlah responden dalam penelitian ini yaitu 20 responden. Data sekunder diperoleh dari literature yang berkaitan dengan penelitian ini. Metode analisis data yang digunakan dalam penelitian ini, dengan menggunakan metode deskriptif kualitatif. Hasil penelitian menunjukan bahwa dinamika kelompok tani Maesaan Waya dikategorikan dinamis dengan perolehan persentase penilaian yaitu $80 \%$. Hal ini disebabkan unsur-unsur dinamika kelompok pada kelompok tani Maesaan Waya berjalan dengan baik. Meskipun unsur-unsur dinamika kelompok berjalan dengan baik tetapi ada unsur dinamika kelompok yang dikategorikan kurang dinamis dengan persentase $20 \%$.
\end{abstract}

Kata kunci: Dinamika, Kelompok Tani, Maesaan Waya, Desa Manembo, Kecamatan Langowan Selatan, Kabupaten Minahasa

\section{PENDAHULUAN}

\section{Latar Belakang}

Sebagai makhluk sosial manusia tidak bisa lepas dari keberadaan orang-orang yang ada disekitarnya seperti keluarga, sekolah, kantor dan dalam hidup bermasyarakat. Keluarga merupakan awal pembelajaran setiap individu untuk bisa bertahan hidup dengan mengenalkan norma-norma kehidupan serta belajar berinteraksi dengan orang lain. Jadi sejak lahir manusia sudah hidup dalam satu kelompok kecil yaitu keluarga. Kelompok akan berjalan atau bertahan apabila dapat dikelola dengan baik. Berjalannya suatu kelompok dilihat dari dimanisnya kelompok tersebut, baik 
kelompok dengan anggotanya maupun anggota dengan anggota kelompok tersebut. Tidak dinamisnya suatu kelompok dapat mengakibatkan kelompok itu tinggal nama saja. Selain itu kelompok akan bertahan jika tujuan kelompok itu jelas, karena sekarang ini banyak kelompok yang terbentuk secara instan yang hanya memenuhi kebutuhan beberapa orang atau oknum yang tidak bertanggung jawab. Dalam kata lain kelompok terbentuk ketika ada bantuan dana pemerintah setelah itu kelompok tersebut sudah tidak berjalan lagi, kelompok tani misalnya. Kelompok dikatakan dinamis apabila kelompok atau organisasi itu efektif dalam pencapaian tujuan-tujuannya. Untuk mengetahui dinamis tidaknya suatu kelompok dapat dilakukan dengan menganalisis perilaku anggota kelompok melalui aspek atau unsur dinamika kelompok (Tuyuwale dalam Damima, 2001).

Kelompok tani dibentuk sesuai kebutuhan dari masyarakat yang memiliki tujuan yang sama dan ingin bekerja sama satu dengan yang lain (Harijati, 2007). Kelompok tani biasanya ditemukan dipedesaan, karena masyarakat dipedesaan sebagian besar memiliki mata pencaharian di bidang pertanian atau sebagai petani. Maesaan Waya merupakan salah satu kelompok tani yang ada di Desa Manembo Kecamatan Langowan Selatan. Ada 10 kelompok tani yang terbentuk di Desa Manembo dan salah satunya adalah Kelompok Tani Maesaan Waya yang saat ini merupakan kelompok tani berkembang. Usaha tani dari kelompok Maesaan Waya saat ini yaitu Jagung, Padi Sawah dan Tanaman Tahunan Cengkih. Hal inilah yang menarik peneliti untuk melakukan penelitian pada Kelompok Tani Maesaan Waya dan yang menjadi fokus penelitian dengan judul 'Diamika Kelompok Tani Maesaan Waya di Desa Manembo Kecamatan Langowan Selatan'.

\section{Rumusan Masalah}

Dari uraian latar belakang maka dapat dirumuskan masalah yang akan diteliti yaitu, bagaimana dinamika kelompok tani Maesaan Waya di Desa Manembo Kecamatan Langowan yang dikaji dari unsur-unsur dinamika kelompok.

\section{Tujuan Penelitian}

Mengetahui dinamika kelompok tani Maesaan Waya di Desa Manembo Kecamatan Langowan yang dikaji dari unsur-unsur dinamika kelompok.

\section{Manfaat Penelitian}

Penelitian ini dapat memberikan kontribusi bagi mahasiswa yang akan melakukan penelitian yang sesuai, juga merupakan bahan masukan dalam rangka lebih memantapkan tercapainya tujuan kelompok tani.

\section{METODOLOGI PENELITIAN}

\section{Tempat dan Waktu Penelitian}

Penelitian ini dilaksanakan di Desa Manembo Kecamatan Langowan Selatan pada Kelompok Tani Maesaan Waya. Penentuan lokasi penelitian ini untuk mempermudah akses bagi penulis dalam proses penelitian karena lokasi penelitian merupakan lokasi tempat tinggal penulis. Penentuan objek penelitian yaitu Kelompok Tani Maesaan waya karena merupakan kelompok tani yang maju dan berkembang yang ada di daerah lokasi penelitian. Penelitian ini dilaksanakan selama tujuh bulan dari bulan Oktober 2016 - April 2017.

\section{Metode Penelitian}

Metode yang digunakan dalam penelitian ini yaitu bentuk penelitian yang mendeskripsikan peristiwa atau kejadian, perilaku orang atau suatu keadaan pada tempat tertentu secara rinci dan mendalam dalam bentuk narasi. Data kualitatif yang diperoleh merupakan keseluruhan bahan, keterangan data fakta-fakta yang tidak dapat diukur dan dihitung secara matematis, tetapi hanya berwujud naratif. Bahan-bahan ini hanya dapat digolongkan dalam bentuk kategori-kategori (Daymont, 2008). Pada penelitian ini kategori yang dimaksud yaitu dinamis, kurang dinamis dan tidak dinamis untuk mengetahui dinamika kelompok tani Maesaan Waya. 


\section{Metode Pengumpulan Data}

Data yang dikumpulkan terdiri dari data primer dan data sekunder. Data primer diperoleh dari wawancara secara mendalam (indepth interview) dengan responden atau informan berdasarkan daftar pertanyaan yang telah disiapkan dan hasil pengamatan langsung atau observasi di tempat penelitian. Wawancara mendalam (in-depth interview) adalah proses memperoleh keterangan untuk tujuan penelitian dengan cara tanya jawab sambil bertatap muka antara pewawancara dengan responden atau orang yang diwawancarai, dengan atau tanpa menggunakan pedoman wawancara di mana pewawancara dan informan terlibat dalam kehidupan sosial yang relatif lama (Hariwijaya 2007). Responden ditentukan 20 responden yang diambil dari anggota kelompok tani. Data sekunder diperoleh dari beberapa media yang bersifat melengkapi data primer yang berhubungan dengan penelitian ini.

\section{Konsep Pengukuran Variabel}

Karakteristik Kelompok Tani, yaitu meliputi Nama kelompok tani, Tahun berdiri, Jumlah anggota kelompok, Luas lahan yang dimiliki kelompok, dan Jenis usaha tani kelompok.

Karakteristik Responden/Informan, yaitu meliputi Nama responden, Umur responden, Jenis kelamin, Jabatan dalam kelompok, Pekerjaan responden, dan Pendidikan responden.

Dinamika Kelompok Tani

Dinamika kelompok terdiri dari beberapa aspek atau unsur yang menentukan kedinamisan suatu kelompok yaitu,

1. Tujuan kelompok tani : $\quad$ Tujuan kelompok tani sesuai dengan apa yang terjadi dilapangan.

2. Struktur Kelompok : Memiliki struktur kelompok dan terdapat pembagian tugas yang jelas dalam pelaksanaan kegiatan.

3. Pengembangan dan pembinaan kelompok: Pengukurannya didasarkan pada kegiatan sosialisasi yang dilakukan dalam mengembangkan wawasan serta pelatihanpelatihan dalam mengembangkan kreatifitas anggota kelompok dan upayaupaya dalam penyediaan fasilitas dalam penyelenggaraan kegiatan kelompok

Kekompakan kelompok : Apakah kelompok tani dapat dikategorikan kompak dilihat dari kerjasama kelompok dalam pencapaian tujuan kelompok.

4. Efektivitas kelompok : Bagaimana efektivitas kelompok tani maesaan waya melihat proses yang dilakukan kelompok dalam pencapaian tujuan kelompok. Proses tersebut dilihat dari kesungguhan dan semangat anggota kelompok dalam melaksanakan setiap kegiatan kelompok guna mencapai tujuan kelompok serta bagaimana kelompok dalam memberikan apresiasi terhadap anggota kelompok dalam pencapaian tujuan.

\section{Metode Analisis Data}

Data yang diperoleh dari hasil penelitian ini akan dianalisa dalam tabel persentase kemudian dideskripsikan secara naratif atau diinterpretasikan sesuai hasil penelitian yang dilakukan berdasarkan dukungan teori yang berkaitan dengan objek penelitian ini. Dalam penelitian ini dilakukan pembagian interval kelas sesuai dengan kategori- kategori yang ditentukan yaitu dinamis, kurang dinamis dan tidak dinamis untuk menentukan dinamika kelompok tani. Perhitungan interval secara matematis menurut Junaedi (2012) adalah:

Keterangan:

$$
i=\frac{a-b}{k}
$$

$$
\begin{aligned}
& \mathrm{i}=\text { Interval kelas } \\
& \mathrm{a}=\text { Jumlah skor/persentase maksimum } \\
& \mathrm{b}=\text { Jumlah skor/persentase minimum } \\
& \mathrm{k}=\text { Jumlah kelas/kategori }
\end{aligned}
$$

$$
i=\frac{100-0}{3}=33.3
$$

Jadi interval kelas yang diperoleh yaitu 33.3, maka untuk persentase dalam kategori yang telah ditentukan yaitu :

$0-33.3 \% \quad=$ Tidak dinamis

$33.4-66.6 \%=$ Kurang dinamis

$66.7-100 \%=$ Dinamis 


\section{HASIL DAN PEMBAHASAN}

\section{Gambaran Umum Lokasi Penelitian}

Manembo adalah salah satu desa yang berada di Kecamatan Langowan Selatan Kabupaten Minahasa. Desa Manembo merupakan desa tempat objek penelitian berada. Luas wilayah Desa Manembo $354 \mathrm{Ha}$ yang terdiri dari 5 jaga. Desa Manembo berbatasan dengan:

- Sebelah Utara berbatasan dengan Desa Winebetan

- Sebelah Timur berbatasan dengan Desa Teep

- Sebelah Barat berbatasan dengan Gunung Kawatak

- Sebelah Selatan berbatasan dengan Desa Atep

Jumlah Penduduk Desa Manembo pada saat penelitian diambil dari data desa tahun 2016 berjumlah 1.400 jiwa dengan jumlah keluarga sebanyak $470 \mathrm{kk}$.

\section{Karakteristik Kelompok Tani}

Maesaan Waya adalah kelompok tani yang menjadi objek penelitian dan bertempat di Desa Manembo Kecamatan Langowan Selatan. Kelompok tani Maesaan Waya berdiri sejak tahun 2001 dan penyegaran tepatnya pada tanggal 17 April 2012 dengan anggota berjumlah 20 orang yang terdiri dari 8 orang Petani Penggarap dan Buruh Tani 12 orang. Struktur organisasi terdiri dari Ketua, Sekertaris, Bendahara, dan anggota. Luas lahan yang dimiliki kelompok tani Maesaan waya yaitu sebesar 45,5Ha, yang terdiri dari $18.5 \mathrm{Ha}$ Sawah, 25 Ha Lahan Kering/Tegalan, dan $2 \mathrm{Ha}$ Pekarangan. Usaha tani yang diusahakan oleh kelompok yaitu tanaman musiman Padi, Bawang, Tomat, Jagung, tanaman tahunan Cengkeh, dan ternak ayam kampung, sapi, itik serta usaha lain kelompok tani maesaan waya yaitu memproduksi Cap Tikus (minuman beralkohol). Selain melakukan kegiatan usaha tani, Kelompok tani Maesaan Waya juga mempunyai beberapa kegiatan seperti, pertemuan rutin seminggu sekali dilaksanakan pada hari sabtu malam dengan kegiatan ibadah, arisan, dan evaluasi kegiatan kelompok tani, Sosial desa, pengumpulan modal dengan kegiatan tabungan anggota, iuran, dan lelang. Tujuan kelompok tani Maesaan Waya yaitu untuk meningkatkan kualitas lingkungan hidup dan meningkatkan pertumbuhan ekonomi masyarakat.

\section{Karakteristik Responden}

\section{Karakteristik Responden Menurut Umur}

Tingkat umur responden dari kelompok tani Maesaan Waya bervariasi, mulai dari responden yang berumur 30-an tahun Sampai 60an tahun. Hal ini dikarenakan tidak ditentukan mengenai tingkat umur dalam penentuan responden. Pengelompokkan umur responden dilakukan dalam upaya mempermudah proses pengolahan data. Kelompok umur dibagi menjadi 4 kelompok umur yaitu $30-40$ tahun, $40-50$ tahun, $51-60$ tahun dan $>60$ tahun. Gambaran mengenai kelompok umur responden dapat dilihat dalam Tabel 1.

Tabel 1. Karakteristik Responden Menurut Tingkat Umur

\begin{tabular}{cccc}
\hline No & Umur (Tahun) & $\begin{array}{c}\text { Jumlah } \\
\text { Responden } \\
\text { (Orang) }\end{array}$ & $\begin{array}{c}\text { Persentase } \\
(\%)\end{array}$ \\
\hline 1 & $30-40$ & 4 & 20 \\
2 & $41-50$ & 9 & 45 \\
3 & $51-60$ & 3 & 15 \\
4 & $>60$ & 4 & 20 \\
\hline & Jumlah & 20 & 100 \\
\hline
\end{tabular}

Sumber : olahan data primer, 2017

Tabel 1 menunjukan bahwa umur responden yaitu dari 30 tahun sampai lebih dari 60 tahun. Umur responden pada interval 30-40 tahun dan $>60$ tahun memiliki nilai persentase yang sama yaitu $20 \%$ masing-masing 4 responden, pada interval umur 41-50 tahun merupakan persentase nilai yang terbanyak atau merupakan umur responden terbanyak dengan persentase $45 \%$ dengan responden sebanyak 9 orang, dan $15 \%$ merupakan persentase yang terkecil yaitu interval 51-60 tahun dengan jumlah responden 3 orang.

Tingkat umur mempengaruhi kemampuan seseorang dalam melakukan aktifitas maupun konsep berpikir seseorang. Seseorang yang memiliki umur lebih muda 
tentunya memiliki kondisi fisik yang lebih kuat, keinginan untuk mencoba hal baru, serta memiliki daya berpikir yang kreatif. Sebaliknya, seseorang yang berumur tua atau usia lanjut cenderung menjaga kesehatannya. Pada penelitian ini umur responden berpengaruh dalam menanggapi pertanyaan dan memberikan jawaban. Responden yang umurnya lebih muda cepat dalam menanggapi pertanyaan dan dalam memberikan jawaban. Sebaliknya dengan responden yang sudah berumur lebih tua, membutuhkan waktu yang lebih lama dalam menanggapi pertanyaan dan memberikan jawaban.

\section{Karakteristik Responden Menurut Pendidikan}

Pendidikan responden pada penelitian ini terdiri dari Sekola Dasar, Sekolah Menengah Pertama, dan Sekolah Menengah Atas. Dari hasil penelitian perolehan persentase dari masingmasing tingkat pendidikan yaitu, SD $45 \%$ atau dengan jumlah responden 9 orang dan merupakan persentase responden terbanyak, dan persentase responden yang terkecil yaitu pada tingkat pendidikan SMP sebesar $25 \%$ atau dengan jumlah responden 5 orang dan jumlah responden pada tingkat SMA $30 \%$ dengan jumlah responden 6 orang. Hasil penelitian ini dapat dilihat dalam Tabel 2.

Tabel 2. Karakteristik Responden Menurut Pendidikan

\begin{tabular}{cccc}
\hline No & $\begin{array}{c}\text { Tingkat } \\
\text { Pendidikan }\end{array}$ & $\begin{array}{c}\text { Jumlah } \\
\text { Responden } \\
\text { (Orang) }\end{array}$ & $\begin{array}{c}\text { Persentase } \\
(\%)\end{array}$ \\
\hline 1 & SD & 9 & 45 \\
2 & SMP & 5 & 25 \\
3 & SMA & 6 & 30 \\
\hline & Jumlah & 20 & 100 \\
\hline
\end{tabular}

Sumber : olahan data primer, 2017

Semakin tinggi tingkat pendidikan seseorang semakin banyak pula pengetahuan atau wawasan yang dimiliki, baik itu menciptakan, menerapkan teknologi baru serta inovasi-inovasi yang baru. Selain itu semakin tinggi tingkat pendidikan seseorang semakin dewasa dalam bertindak dan mudah memahami setiap persoalan yang dihadapinya. Dalam penelitian ini tingkat pendidikan responden berpengaruh dalam menanggapi pertanyaan dan memberikan jawaban. Responden yang tingkat pendidikannya paling rendah sulit memahami pertanyaan dalam bahasa baku begitu juga dalam memberikan jawaban, hal ini membuat peneliti harus menyesuaikan dengan bahasa yang mudah dimengerti oleh responden. Sedangkan Responden yang tingkat pendidikannya lebih tinggi cepat tanggap dalam menanggapi pertanyan dalam bahasa baku begitu juga memberikan jawaban.

\section{Dinamika Kelompok Tani}

Penilaian dinamika kelompok pada kelompok tani maesaan waya dilihat dari dalam kelompok itu sendiri yang meliputi anggota kelompok tani.

\section{Tujuan Kelompok Tani}

Setiap organisasi memiliki tujuan yang ingin digapai pada saat terbentuknya suatu organisasi tersebut. Pada penelitian ini yaitu Kelompok Tani Maesaan Waya yang menjadi objek penelitian. Berdasarkan wawancara langsung pada responden Tujuan Kelompok Tani Maesaan Waya yaitu untuk meningkatkan kualitas lingkungan hidup dan meningkatkan pertumbuhan ekonomi masyarakat terutama yang tergabung dalam kelompok tani melalui usaha tani yang diusahakan kelompok tani Maesaan Waya. Berdasarkan pertanyaan pada saat wawancara pada responden mengenai kesesuaian tujuan kelompok tani dengan kenyataan yang terjadi dilapangan menyatakan bahwa tujuan kelompok tani yang ditetapkan sebelumnya sesuai dengan apa yang terjadi dilapangan. Artinya dengan adanya Kelompok Tani Maesaan Waya membantu masyarakat dalam meningkatkan pertumbuhan ekonominya, terlebih yang tergabung dalam kelompok. Dari hasil penelitian $100 \%$ atau 20 orang responden mengatakan atau memberikan jawaban sama.

\section{Struktur Kelompok Tani}

Suatu kelompok atau organisasi memiliki struktur kelompok yang jelas agar terdapat pembagian tugas yang jelas dalam pelaksanaan kegiatannya. Dari hasil penelitian yang dilakukan melalui wawancara langsung 
dengan responden menyatakan bahwa Kelompok Tani Maesaan Waya memiliki Struktur organisasi yang jelas dan pembagian tugas yang jelas pula dalam pelaksanaan kegiatannya. Artinya $100 \%$ responden menyatakan atau memberikan jawaban yang sama. Hasil penelitian dapat dilihat pada tabel 3 (terlampir).

\section{Pengembangan dan Pembinaan Kelompok Tani}

Penilaian untuk pengembangan dan pembinaan kelompok dilakukan berdasarkan ada tidaknya usaha-usaha yang berorientasi memelihara dan mengembangkan kehidupan kelompok. Pengukurannya didasarkan pada kegiatan sosialisasi yang dilakukan dalam mengembangkan wawasan serta pelatihanpelatihan dalam mengembangkan kreatifitas anggota kelompok dan upaya-upaya dalam penyediaan fasilitas dalam penyelenggaraan kegiatan kelompok. Hasil penelitian pada unsur pengembangan dan pembinaan kelompok kesimpulan jawaban dari responden yaitu dalam kelompok tani maesaan waya selalu melakukan upaya-upaya dalam pengembangan dan pembinaan kelompok, baik melalui sosialisasi dan pelatihan-pelatihan untuk menambah wawasan serta meningkatkan kreatifitas kelompok serta upaya penyediaan fasilitas dalam pelaksanaan kegiatan dalam pencapaian tujuan kelompok. Hal ini dilihat dalam persentase jawaban responden yaitu $100 \%$ dengan kategori penilaian pada unsur ini yaitu dinamis. Hasil penelitian dapat dilihat dalam table 3 (terlampir).

\section{Kekompakan Kelompok Tani}

Kekompakan kelompok merupakan kesatuan kelompok yang dicirikan oleh keterikatan yang kuat di antara anggota. Kekompakan kelompok menggambarkan kekuatan kelompok untuk bertahan dari tekanan yang berasal dari luar maupun dari dalam kelompok. Penilaian pada unsur kekompakan kelompok pada penelitian ini yaitu dilihat dari kerja sama, keharmonisan antar anggota dalam kelompok untuk mencapai tujuan yang sudah ditentukan. Hasil dari penelitian pada unsur kekompakan kelompok menjelaskan bahwa dalam penilaian terhadap unsur kekompakan kelompok terdapat dua kesimpulan jawaban yang berbeda dari responden yaitu kompak dan kurang kompak. Untuk persentase responden yang menyatakan kompak lebih tinggi dibanding dengan yang menyatakan kurang kompak, dimana persentase yang menyatakan kompak $60 \%$ dengan jumlah responden 12 orang yang dikategorikan dinamis sedangkan persentase yang menyatakan kurang kompak $40 \%$ dengan jumlah responden 8 orang yang dikategorikan tidak dinamis. Untuk responden yang menyatakan bahwa kelompok tani maesaan waya dikategorikan kompak, dilihat dari keberhasilan pencapaian tujuan kelompok sedangkan untuk responden yang menyatakan bahwa kelompok tani maesaan waya dikategorikan kurang kompak dilihat dari pencapaian tujuan kelompok tani hanya dilakukan oleh sebagian anggota kelompok saja, masih ada anggota kelompok yang kurang ambil bagian dalam setiap pelaksanaan kegiatan kelompok dalam pencapaian tujuan kelompok. Dalam kata lain sebagian anggota melakukan setiap proses dalam pencapaian tujuan tetapi tidak sepenuhnya.

\section{Efektivitas Kelompok Tani}

Penilaian unsur efektivitas kelompok pada kelompok tani maesaan waya yaitu melihat bagaimana proses yang dilakukan kelompok dalam pencapaian tujuan kelompok. Proses tersebut dilihat dari kesungguhan dan semangat anggota kelompok dalam melaksanakan setiap kegiatan kelompok guna mencapai tujuan kelompok serta bagaimana kelompok dalam memberikan apresiasi terhadap anggota kelompok dalam pencapaian tujuan. Hasil penelitian terhadap unsur efektivitas kelompok menjelaskan bahwa kelompok tani maesaan waya efektiv dalam menjalani setiap proses untuk pencapaian tujuan kelompok. Kelompok tani maesaan waya memperhatikan setiap anggota kelompok dalam pencapaian hasil oleh anggota kelompok tani. Artinya anggota kelompok tani semangat dalam menjalani setiap proses untuk pencapaian tujuan. Dari hasil penelitian persentase jawaban 
yaitu $100 \%$ atau 20 responden memberikan jawaban yang sama. Dari hasil wawancara dilapangan responden menyatakan bahwa kelompok tani maesaan waya bukan hanya memperhatikan anggota kelompok saja bahkan memperhatikan lingkungan sosial tempat aktifitas kelompok berada.

\section{Rekapitulasi Penilaian Dinamika Kelompok Tani Maesaan Waya}

Rekapitulasi penilaian unsur dinamika kelompok pada kelompok tani maesaan waya dapat dilihat pada tabel 3 (terlampir). Dari hasil penelitian diperoleh total persentase untuk kategori dinamis sebanyak $400 \%$ dan untuk Persentase kategori tidak dinamis $100 \%$. Perhitungan dengan menggunakan rumus matematis menurut Junaedi (2012) yaitu,

$$
\begin{array}{r}
Y=Y_{1}+Y_{2}+Y_{3}+Y_{4}+Y_{5} \ldots \ldots \ldots . . d s t \\
=\text { Dinamika Kelompok }
\end{array}
$$

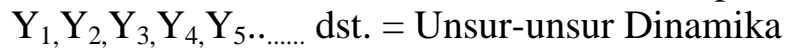
Kelompok.

Dari perolehan jumlah persentase tertinggi $400 \%$ diperoleh rata-rata persentase $80 \%$ dan dari perolehan persentase terendah $100 \%$ diperoleh rata-rata persentase $20 \%$. Dari perolehan persentase sebesar $80 \%$ berada pada interval $66.7 \%$ - $100 \%$ maka kelompok tani maesaan waya dikategorikan kelompok tani yang dinamis. Hal ini menunjukkan bahwa unsur dinamika kelompok pada kelompok tani maesaan waya berjalan dengan baik. Artinya interaksi sosial kelompok dari interaksi didalam berjalan dengan baik sehingga tujuan yang ingin dicapai oleh kelompok ataupun tujuan tiap anggota tercapai.

\section{KESIMPULAN DAN SARAN}

\section{Kesimpulan}

Dari hasil dan pembahasan :

1. Tujuan kelompok tani sesuai yang terjadi dilapangan dengan nilai $100 \%$.

2. Struktur kelompok tani memiliki pembagian tugas yang jelas dengan nilai $100 \%$.
3. Pengembangan dan pembinaan kelompok tani berjalan dengan baik dengan nilai persentase $100 \%$.

4. Kekompakan kelompok tani kurang dinamis dengan nilai $60 \%$.

5. Efektiv dalam pencapaian tujuan kelompok dengan nilai $100 \%$,

Dengan nilai persentase $80 \%$ maka Kelompok Tani Maesaan Waya di kategorikan dinamis.

\section{Saran}

Dinamika Kelompok Tani Maesaan Waya harus dipertahankan, karna kelompok tani ini merupakan panutan bagi kelompok tani yang ada di Desa Manembo dan lebih ditingkatkan lagi unsur kekompakan kelompok.

\section{DAFTAR PUSTAKA}

Damima, V., 2001. Dinamika Kelompok Tani Padi Sawah di Kecamatan Tondano Kabupaten Minahasa. Studi Kasus Terhadap Kelompok Tani di Desa Tataaran 1. Skripsi Fakultas Pertanian Universitas Sam Ratulangi. Manado

Daymon, C., 2008. Metode-Metode Riset Kualitatif dalam Public Relations dan Marketing. Bentang. Yogyakarta

Departemen Pertanian. 2007. Modul Dinamika Kelompok Deptan RI. Jakarta

Harijati, 2007. Sumber Daya Manusia dan Kinerja Petani Sebagai Basis Pengembangan Ekonomi Lokal. Studi Kasus Desa Tegallega Kecamatan Warungkondang Kabupaten Cianjur. Jurnal ASAPPK. Vol.12.

Hariwijaya, M., 2007. Metodologi dan teknik penulisan skripsi, tesis, dan disertasi. Matera Publishing. Yogyakarta 
Hermanto, 2007. Rancangan Kelembagaan Tani dalam Implementasi Prima Tani di Sumatera Selatan. Jurnal Analisis Kebijakan Pertanian. Vol.5.

Huraerah, A., dan Purwanto. 2006. Dinamika Kelompok. PT. Refika Aditama. Bandung

Munir, B., 2001. Dinamika Kelompok, Penerapan dalam Laboratorium Ilmu Perilaku. Universitas Sriwijaya. Palembang.

Junaedi, A., 2012. Dinamika Kelompok Tani Padi Sawah di Kampung Banjar Ausoy Distrik Manimeri Kabupaten Teluk Bintuni. Skripsi Fakultas Pertanian dan Teknologi Pertanian Universitas Negeri Papua. Manokwari. Diakses Pada 25 September $2016 \quad$ dari http:/eprints.Unipa.ac.id/
Saleh, A., 2012. Kumpulan Bahan Kuliah Manajemen Kelompok dan Organisasi. Program Studi Ilmu Penyuluhan Pembangunan. Sekolah Pascasarjana IPB. Bogor.

2015. Materi Pokok Dinamika
Kelompok. Universitas
Tangerang Selatan.

Santoso, S., 2004. Dinamika Kelompok. PT. Bumi Aksara. Jakarta

Sarwono, S., 2005. Psikologi Sosial Psikologi Kelompok dan Psikologi Terapan. PT. Balai Pustaka. Jakarta

Suwandi, A., 2006. Administrasi Penyuluhan. Universitas Terbuka. Jakarta

Thomas, S., 2005. Dinamika Kelompok. Universitas Terbuka. Jakarta 